trespass on the columns of your journal with a few particulars of a case in point.

An assistant-surgeon in the army, an old friend of mine, with whom $I$ corresponded during his tour of scrvice of between two and three years on the west coast of Africa, is the gentleman whose career affords an example of Professor Tufnell's statement. The number of civil posts which he held is, I believe, without parallel in so short a period; the arduous and important duties of these he was rendered capable of discharging satisfactorily only by a good liberal education, strict integrity, and sound common sense. For these reasons, he was intrusted with such posts and powers by the governor of the colony. Having been appointed justice of the peace by commission within a few months of his arrival in the colony of the Gold Coast, Dr. A, Graves Power was, after fifteen months' experience of his qualifications, selected to fill the highest post in those parts, next to that of governor-namely, acting chief justice, while he was still an assistant-surgeon.

Within a period of thirty months, this gentleman held no less than ten civil and two military appointments.

My friend arrived at the Gold Coast in July, 1854, and in five months after was appointed justice of the peace and chief officer of customs for Quitta; then, at Cape Coast, (the seat of government, acting asoistant juliciul assessor, one ot the custodes of the treasury keys, physician to the natives, coroner, colonial surgeon, principal military medical officer, acting chief justice, member of legislative conncil, and member of executive council, (pio tem.) On the day of his leaving the Coast for Europe, lie received from his excellency Henry Connor, the acting governor, a most flattering and complimentary letter, at the same time regretting his (my friend's) being compelled by illness to leave the colony.

Dr. Power arrived from Africa in October, 1856, and is at present doing duty at St. Mary's Barracks, Chatham. I regret to say that his health is not yet re-established sufficiently to allow of his taking duty in a tropical climate.

My object, Sir, in requesting your insertion of the above is to corroborate by an example the statement of Professor Tufnell, who holds out to the well educated and discreetly behaved medical officer the chance of being "a governor, diplomatist, or judge."

Paddington, Dec. 1857 I am, Sir, your obedient servant, M.B. LOND.

\section{ON THE TREATMENT OF MENTAL DISEASES WITHOUT THE USE OF ALCOHOL. To the Editor of THE LANCET.}

SIR,-In THE LANCET of the 19th inst., appears a letter by a correspondent, signing himself "Verax," in favour of alcoholic stimulants in mental diseases. I would ask him what are the medicinal and NUTRITrous properties of alcoholic stimulants which he thinks requisite for the insane, such as beer, stout, wine, and brandy? I would ask him also, if he has paid particular and constant attention for the last twenty years to the effects of alcoholic stimulants, even moderately taken, on the organs of the human body, particularly the brain ?

Nottingham, Dec. 1857.

I am, Sir, yours obediently, John Hrgginbottom, F.R.S.

\section{THE BLOODLETTING CONTROVERSY.}

\section{To the Editor of The LANCET.}

SIR,-In the hurried communication I sent you, which appeared in your journal of the 12th instant, on the Bloodletting question, I omitted stating my opinion as to the change of type of inflammatory diseases, now undergoing such discussion.

In the course of my experience I cannot say that I have observed any such alteration. The cases I related bore precisely the same symptoms and character they did five-and-thirty years ago, and in the treatment of which a free use of the lancet would then alone have been efficacions.

Now, though I discover little or no change in the type of these diseases, I fully acknowledge, from long experience, that in the treatment considerable modification of the old practice is absolutely necessary ; and notwithstanding a careful perusal of Dr. Markham's somewhat protracted speculative observations, I am bound to say - from practice, not theory - that not only is bloodletting now seldom necessary, but frequently highly prejudicial, and this, as I have before remarked, without perceiving any marked alteration in the character of the disease. I am, Sir, your obedient servant,

Pembroke Dock, Dec. 1857.

\section{THE ROYAL INFIRMARY, EDINBURGH.}

\author{
To the Editor of THE LANCET.
}

SIR,--Seeing a letter in your journal from a gentleman signing himself "M.D. Edin.," pointing out the present position of strgery in the University of Edinburgh, I beg to malie a few remarks on it.

He says-" "In every other medical school the teaching of surgery is held to be of importance; here, seemingly, it is not." Now, tirst, the writer of the above could never have been a student in the Edinburgh Infirmary, or, if so, must have been very negligent in his attendance on the surgical practice. I am well aware that Professor Miller, the lecturer on surgery in the University, has only two small wards, and it is not necessary that a lecturer on the principles of surgery should have any wards at all. It is the lecturer on clinical surgery who requires a sufficient number of beds to present to his class cases which are the subjects of his lectures; for which purpose Professor Syme, the lecturer on clinical surgery in the University, has about 100 allotted to him; and the lecturer on clinical surgery to the College of Surgeons has also a large number of beds for the same purpose. Having studied in Tdinburgh, London, and Dublin, I can say, withont fear of contradiction, that there is no institution in Great Britain where surgery is so well taught as in the Edinburgh Infirmary, and students come from all parts of the world to attend the practice of it, so highly is it looked upon; and it is to the Edinburgh school that London is indebted for some of its best surgeons.

I am, Sir, your obedient servant,

Bristol, Dee. 1857 .

A SUBSCRIBER.

THE

\section{OPERATION FOR THE CURE OF PROLAPSUS} AND PROCIDENTIA UTERI.

\section{To the Editor of THE LANCET.}

SiR,-In reference to a long communication by Dr. Vernon, on Prolapsus Uteri, I beg, in the first place, to observe, that I shall not dwell on the spirit or good sense of that gentleman's letter, either as regards myself or the reporter of your jonrnal; but if Dr. Vernon had simply desired truthfulness, he would have referred to the report in your "Mirror" of Nov. 22nd", 1856, p. 567 , where one of the two cases which he quotes is actually reported as unsuccessful; and, again, in another weekly journal, the oth $\in \mathrm{r}$ case is fully and truthfully reported.

In common justice to myself, I must refer the profession to my many and candid reports of all my operations, under various heads, in your own and other journals, and request of them not to judge me as harshly as Dr. Vernon has done, because $I$ answered off-hand some general questions put to me at a time of sickness, and as can and will be proved by other testimony, without the slightest intention of deceiving the profession: It may be as well to wait till the general summary has appeared to the reports now in progress.

I must, however, positively refuse to answer any more letters from Dr. Vernon, for two reasons : first, because he writes with great personal animosity; secondly, because $I$ do not think it right that a resident officer in an hospital should attack his late superior by using notes of his cases in the way just done.

Trusting, in fairness, you will find space for this short note in this week's LANCET

I am, Sir, your obedient servant,

Connaught-square, Dec. 1857.

I. BAKER Brown, F.R.C.S.

\section{DIPHTHERTTE.}

\section{To the Editor of The Lancet.}

SIR,-The above disease, of an exceedingly virulent type, has, within the last two months, been raging in a very unhealthy part of my district-the village of Nop Mayo, a place in which the mortality during the cholera epidemic of 1848 was far in excess, in proportion to the inhabitants, of any other place. The synuptoms are those reported by previous correspondents, - viz., low fever, swelling of the maxillary glands, sudden and extensive formation of sloughs in the pharyn $x$ and fauces, hæmorrhage from the throat and nose, with a most fotid discharge from the latter. I have lost six cases out of thirteen. In one, all traces of the diphtherite had subsided, and the little patient (aged sixteen) was gaining strength, and able to get ont of doors, when, seven days after, he was taken ill with croup, and died in six hours. In another case the throat symptoms were in abeyance three weeks, and the patient, becoming anarsarcous, sunk from exhaustion. The worst 